\title{
Education for Sustainability in Higher Education
}

DOI 10.18267/pr.2021.krn.4816.5

\author{
Katarína Chomová \\ ORCID iD: 0000-0001-5819-2963 \\ katarina.chomova@euba.sk \\ University of Economics in Bratislava, Faculty of Commerce, Department of Marketing \\ Bratislava, Slovakia
}

\begin{abstract}
Education is the most powerful instrument that can be used to change the world. Business students of today are future executives in companies and governments. Therefore, their education for sustainability needs to be carefully considered. Education for sustainability in higher education has gained strongly increasing attention. The purpose of this paper is to describe the components of a sustainability education: (1) university management (2) academics and pedagogies and (3) students, with specific focus on students in business management/marketing. Using the "Responsibility assignment matrix (RACI MATRIX)" we describe responsibility of these three components for activities supporting education for sustainability. This article also argues that education for sustainability is urgently needed to provide but also describe barriers for change in higher education for sustainable development.
\end{abstract}

Keywords: education, higher education institutions, sustainable development

JEL Classification codes: M31

\section{INTRODUCTION}

Societies across the globe are facing new challenges arising from the pace of technological progress and globalization. These include growing complexity and uncertainty, increasing individualization and social diversity, expanding economic and cultural uniformity, degrading ecosystem services upon which societies depend, and heightened vulnerability and exposure to natural and technological hazards.

Additionally, these societies now have a vast and continuous stream of information at their disposal. The complexity of these challenges - including the variety of actors involved, the situation and the courses of action - does not allow for straightforward problem-solving processes and instead necessitates creative and self-organized action.

In this new reality, universities should operate as knowledge and reflection institutions developing critical and systemic thinking and not only as teaching institutions that transfer knowledge (Filho et al., 2008)

In order to contribute to sustainable development, students need to learn how to understand the complex world in which they live, and how to deal with uncertainties, trade-offs, risks and the high velocity of societal (global) change. They need to be able to collaborate, speak up and act for positive change within the world (Wals, 2015; Wals \& Lenglet, 2016).

The concept of education for sustainable development was born from the need for education to address the growing environmental challenges facing the planet. In order to do this, education must change to provide the knowledge, skills, values and attitudes that empower learners to contribute to sustainable development. At the same time, education must be strengthened in all agendas, programs and activities that promote sustainable development. 
In short, sustainable development must be integrated into education and education must be integrated into sustainable development (UNESCO, 2014).

Education for sustainable development aims to produce learning outcomes that include core competencies such as critical and systemic thinking, collaborative decision-making, and taking responsibility for present and future generations.

\section{LITERATURE REVIEW}

Since the concept of sustainable development was presented in the Brundtland report Our Common Future' (WCED, 1987), education has increasingly been called upon to integrate issues of sustainability, and to contribute to a sustainability transition process in society.

Education for sustainable development was a United Nations program that defined as education that encourages changes in knowledge, skills, values and attitudes to enable a more sustainable and just society for all (UNESCO, 2014).

Since traditional single-directional delivery of knowledge is no longer sufficient to inspire learners to take action as responsible citizens, education for sustainable development entails rethinking the learning environment, physical and virtual.

For UNESCO, education for sustainable development involves integrating key sustainable development issues into teaching and learning. This may include, for example, instruction about climate change, disaster risk reduction, biodiversity and poverty reduction and sustainable consumption.

It also requires participatory teaching and learning methods that motivate and empower learners to change their behaviors and take action for sustainable development. ESD consequently promotes competencies like critical thinking, imagining future scenarios and making decisions in a collaborative way.

One definition of Education for Sustainable Development is an "interdisciplinary learning methodology covering the integrated social, economic, and environmental aspects of formal and informal curriculum" (UNESCO, 2014).

Universities have a strategic role in the world, especially in respect of sustainable development and their work to prevent a global collapse (Bilodeau et al., 2014; Ferrer-Balas et al., 2009; Howlett et al., 2016; Filho et al., 2015; Moore, 2005). Teaching, research, operations, and relations with local communities should be thought of as activities integrated to reflect the principles of sustainability. According to Filho et al. (2015), about 600 universities around the world have adopted this new vision of education for sustainability.

According to Klimková (2017), despite the relatively long tradition of environmentally oriented trade unions in the countries of Central and Eastern Europe, it turns out that the concept of "Education for Sustainable Development" has not been adopted in the Slovak context.

Klimková (2017) performed a content analysis of documents of selected study programs of teachers, which showed:

(1.) for competences of sustainable development are not given attention generally,

(2.) there are obvious fundamental gaps and shortcomings of university practical

professional training of teachers towards sustainability, which represents barriers for its

implementation in school practice.

As some experts and theorists have stated, the reason why this is so will, it seems, be hidden in the fact that it is a fundamentally new type of education, transdisciplinary, open. "Complex social problems require hybrid solutions" (Vladyková, 2015), which presupposes constant 
discourses and cooperation taking place across the natural sciences, social sciences and humanities, and the practical sphere of civil society. It is an educational concept (interdisciplinary in nature), which is relatively difficult to transform into specific educational and study programs and which places high demands on the diverse competencies of teachers, related to creativity and the development of noncognitive skills much more than theoretical expertise. At the same time, it presents a challenge and requirements to implement the concepts of sustainability and sustainable development into the undergraduate teacher training, regardless of approvals, for all study programs (Klimková, 2017).

\section{METHODOLOGY}

Education for sustainability in higher education has gained strongly increasing attention. In this context, the paper aims to evaluate and concentrate on the current knowledge base in the field of education for sustainable development and to clarify the basic approaches and strategies of sustainable education in higher education institutions.

Theoretical background of the paper presents topics based on relevant literature sources. This article reviews the literature regarding components of a sustainability education: (1) university management (2) academics and pedagogies and (3) value of students. Numerous views have been adopted in the education design. However, very scarce attention has been devoted to the students themselves whose capabilities and characteristics affect the reception of new views and are at the core in terms of achieving the sustainability goals (Bask et al., 2020).

The main methods used in this paper include analysis, comparative method, synthesis and deduction. The method of deduction was used to logically justify the conclusions from the generally valid pragmatic experience abroad.

In section discussion we used "Responsibility assignment matrix (RACI MATRIX)" to describe responsibility for activities supporting education for sustainability. RACI MATRIX describes the participation by various roles in completing tasks or deliverables for a project or business process. RACI is an acronym derived from the four key responsibilities most typically used: $R-$ responsible (those who do the work to complete the task), A - accountable (final approving authority/ an accountable must approve work that responsible provides), C- consulted (those whose opinions are sought), and I- informed (those who are kept up to date on progress).

\section{RESULTS AND DISCUSSION}

\subsection{University management}

The integration of sustainability, e.g., by means of competences for sustainable development, requires an organizational change process in higher education institutions (Lambrechts, 2018).

According to Filho et al. (2008) an increasing societal awareness on sustainable development challenges, as well as the urgency required to tackle them, contrast with limited progress in the integration of sustainable development in university curricula. Ramos et al. (2015) remarked that despite the efforts of many universities in integrating sustainable development into the curricula, it has been recognized that changes have been little and that they have been occurring at a slow pace (Watson et al., 2013).

According to Lambrechts et al. (2018) transformation in learning in education for sustainability requires the commitment of faculty and academics. With their efforts, motivation, and innovative ideas, change in content and methods can materialize. Examples of whole curriculum reform and its reorientation towards sustainability are relatively limited (Von 
Blottnitz et al., 2015). It is worth highlighting that in higher education institutions there is often no adequate institutional support and incentives for those academics willing to integrate sustainable development in their activities (Hoover and Harder, 2014), and most of the efforts lie primarily on overcommitted academics (Krizek et al., 2012).

The combination of both strategies (whole curriculum reform and individual specialized courses) have been indicated as beneficial for embedding sustainable development in higher educational institutions (Mulder et al., 2012).

Whole university approaches, connecting different functions such as teaching, research, campus operation and strategies aimed at communities and stakeholders' engagement and participation, have been indicated as essential for embedding sustainability in in higher educational institutions (Lozano et al., 2015; Sterling, 2013)

Based on Sterling (2011) change in sustainability education can be executed on three levels, ranging from a weak to a strong view of sustainability. His work is based on Bateson's (1972), cited in Sterling (2011) three orders of learning and change.

First-order change refers to "more of the same", in other words change within a special area without questioning the assumptions or beliefs of the learner e the aim is to "do things better" and improve existing systems. According to Sterling (2011), most teaching in higher education based on transmissive pedagogies represents this level, the aim being to transfer knowledge rather than to challenge paradigms or students' beliefs.

The second-order change, or level 2 of learning also recognizes other than the dominant paradigm and aims at "doing better things". Learners are already required to review their values critically and possibly even to change them. This is a challenge for the student, who must consider all information, including what has previously been learned, from a critical perspective. The goal on the first-order level is to increase efficiency, whereas on the secondorder level it is to find out what purposes the increased efficiency serves. The learning on this latter level is transformative.

The third level is even more challenging: Sterling (2011) describes it as "seeing things differently" and it involves a paradigm change.

\subsection{Academics and pedagogies}

Individual values of academics in higher education institutions influence the content, learning outcomes and pedagogy used in teaching. Values play a key role in the way an academic will respond to proposals to educate for sustainable development and influence how their disciplines develop (Thomas, 2016).

We need a new generation of professionals that think and take decisions within this new perspective and it is necessary to modernize higher education structures towards sustainability (Bilodeau et al., 2014; Filho et al., 2015).

Scott (2002) describes different responsibilities for educators:

(1) To help learners understand why the idea of SD ought to be of interest to them;

(2) To help learners gain plural perspectives on issues from a range of cultural stances;

(3) To provide opportunities for an active consideration of issues through appropriate pedagogies which, for example, might begin from learners' and teachers' different interests, helping pupils understand what they are learning and its significance.

(4) To encourage students to continue to think about what to do, individually and socially, and to keep their own and other people's options open. 
Opinions are divided regarding sustainability competences; whether to integrate 'new' competences, or to reorient existing competences within a framework of sustainability (Lambrechts, 2017).

Competences for sustainable development have been defined as a way to enable students to cope with the complexity and uncertainty of sustainability issues, thereby strongly opposed to classical educational models, focusing on more knowledge transfer (Wiek et al., 2014).

Specifically, in the context of management education, sustainability competences have been analyzed as well, focusing on the competences of (corporate) change agents for sustainability (Hesselbarth et al., 2015). Within an analysis of bachelor programs in business management, (Lambrechts et al., 2018) concluded that competences related to systems thinking, future thinking, action skills and personal involvement.

\section{Fig. 1 Key competencies and performance of sustainability citizens}

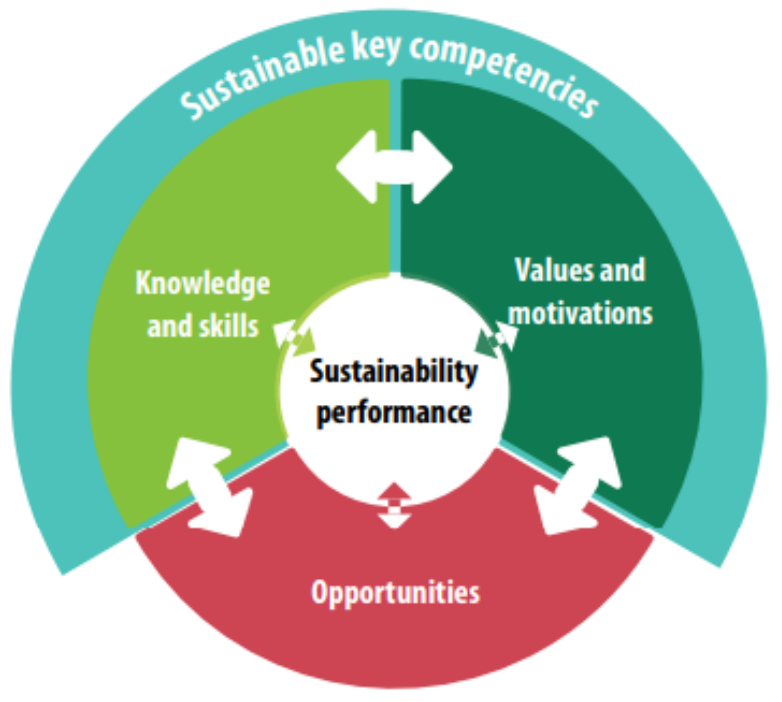

Source: Leicht et al., 2018, p. 46

According to Leicht et al. (2018) sustainability performance depends on the interplay of knowledge and skills, values and motivational drivers, and opportunities. The interrelation of these dimensions influences personal behavior (Figure 1).

The transformation in higher education towards sustainability should encourage inter and transdisciplinary approaches (Ferrer-Balas et al., 2009; Moore, 2005; Remington-Doucette et al., 2013; Sterling, 2013), the integration of theory and practice (Moore, 2005), the ethical discussions and reflections (Howlett et al., 2016) and the adoption of critical thinking (FerrerBalas et al., 2009; Howlett et al., 2016).

\section{- transdisciplinary approaches}

Transdisciplinary approach is increasingly accepted as necessary in addressing complex, multistakeholder real-life problems with high social and environmental relevance such as those characterizing sustainable development. These principles can be successfully integrated into innovative teaching practices.

Despite the lessons learned from best practices in implementing an inter-transdisciplinary approach by changes integrated into curricula, teaching and collaboration with community, 
threats to these processes are being identified within several studies regarding barriers to integration of sustainability in universities (Dyment, 2015). Roots of those challenges are often found in the traditional departmental, compartmentalized structure of universities (Savelyeva, 2012) and its disciplinary boundaries (Moore, 2005). Traditional division of sciences and disciplinary orientations in universities reflect general fragmentation of learning, still prevailing at all the levels of education and in various research areas, contradicting requirements from education and teaching to contribute to "transformation of society for XXI century". Selfreflection on transformative potential of universities and the role of teachers and other change actors is necessary but not sufficient for overcoming disciplinary barriers.

In efforts to bridge the gap between traditional and newly projected role of universities, authors often see the solution in the quality of teaching, adding significant responsibility to the already complex role of teachers.

\section{- integration of theory and practice}

The integration between practice and theory can be done by two general forms: the approach between university and community and the use of the campus as a learning laboratory (FerrerBalas et al., 2009; Wiek et al., 2014). Higher education institutions can develop local or even global communities of practice for sustainability learning. This interdisciplinary working groups can list the problems experienced by the community and they can become topics to be debated in the classroom. Educators and students can use the theory taught in the discipline to perform the real projects mentioned (Barber, 2014; Ferrer-Balas, 2009; Wiek, 2014). Besides, the inclusion of students in the dialogue with communities can present opportunities to learn and understand different points of view (Too, 2015).

Besides of the two general forms mentioned above, it is worth highlighting service-learning in the framework of internship programs placing students in developing countries in collaboration with international and local NGOs. These initiatives encourage students to put into practice the theoretical knowledge acquired and to find practical relevance in what they have studied in these sometimes 'extreme' experiences in developing countries. Boni et al. (2015) pointed out that these experiences have a strong impact on student's assumptions and worldview.

Student engagement through service-learning with local or international communities have a clear transformative potential for students, challenging their own stereotypes and personal values, which involves learning as change throughout the educational community is a shift towards higher order learning (Sterling, 2013).

\section{- critical thinking}

Critical thinking skills and information literacy are key issues to be integrated in higher education (Peters, 2017). As such, critical inquiry should be framed within the context of wicked sustainability issues, characterized by their complexity and uncertainty (Lambrecht, 2018).

Therefore, rather than introducing knowledge-based sustainability education, the selfregulated learning approaches should be combined with an extensive focus on developing critical and interpretational competences.

The author stressed the inclusion of dimensions such as ethics, aesthetics and culture, also non-material values such as mutual help, solidarity and compassion are emerging issues that have been neglected in previous approaches. 


\subsection{Value of students}

Generally, it is stated in the literature that students have very low understandings of sustainability (Chaplin, 2014) or reduce sustainability issues to environmental issues, thereby lacking a systemic perspective (Clark \& Zeegers, 2015). Yet the environmental dimension of sustainability is most frequently identified and described in the literature (Cotton \& Alcock, 2013).

Regarding student engagement in sustainability, it is clear that values as well as attitude shaping (Zsoka et al., 2013) are important for sustainability behaviors. However, a value action gap is perceived: while students believe sustainable living is important, they are hesitant to take personal action, mostly due to the displacement of responsibility to other people or organizations and reluctance to think about lifestyle changes in favor of sustainability (Chaplin, 2014).

The student perspective in business management study programs is often linked to a focus on the bottom line and self-serving characteristics, instead of the triple bottom line, commonly used in CSR settings (Lambrechts et al., 2018)

Lambrechts et al., (2018) identify different segments in the student population. Results of the segmentation study reveal that there is no universal students' perspective on sustainability. Within the group of business management/marketing students, four different segments could be identified, each with specific attitudes toward sustainability (Figure 2).

The first segment (26\%) thinks humans can solve environmental problems. Respondents in this segment are interested in environmental issues and read and talk about it. Nevertheless, they don't avoid over-consumption and they are not saving energy. Their efforts toward sustainability are oriented toward food. Furthermore, they think everyone should contribute to sustainability. This segment can be labeled as the "Moderate problem solvers".

The second segment (22\%) is rather pessimistic, as they think that environmental issues cannot be solved. The respondents within this segment are not interested in environmental issues and are not willing to take efforts to be sustainable, they do not expect this from other people either. This segment can be labeled as the "Pessimistic non-believers".

The third segment (36\%) is rather optimistic about the possibilities of humans to solve environmental issues. Respondents within this segment do not read or talk about environmental issues but they deliver efforts to be sustainable: they avoid overconsumption, they save energy and they try to eat sustainable. Furthermore, they think everyone should pay efforts to be more sustainable. This segment can be labeled as the "Optimistic realists".

The fourth segment (16\%) thinks humans could solve environmental issues. Respondents within this segment are very interested in environmental issues and read and talk about it. They are sustainable in trying to avoid over-consumption and saving energy, but don't do efforts regarding food. Also, they do not expect everyone to contribute to the sustainability transition. This segment can be labeled as the "Convinced individualists". 
Fig. 2 Schematic overview of segmentation of business management/marketing students

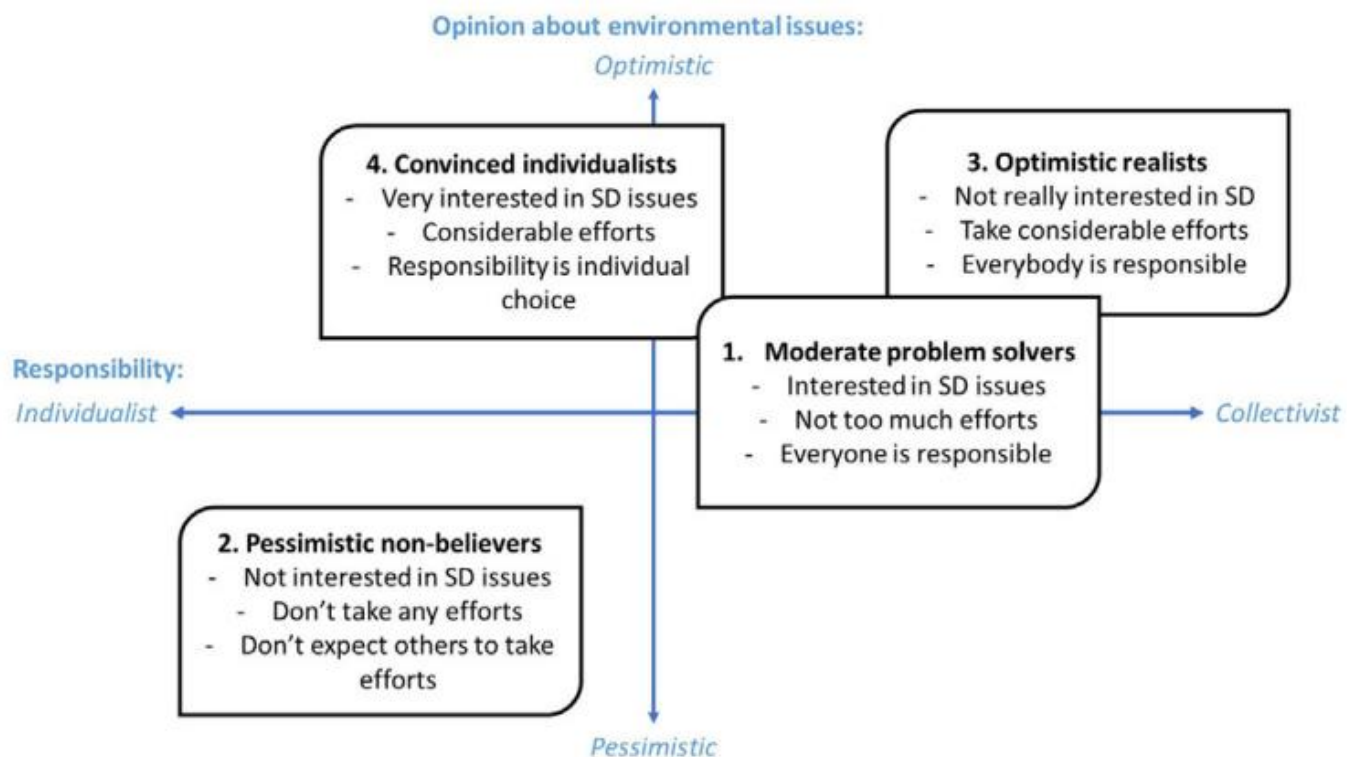

Source: Lambrechts, 2018, p. 568

The segmentation study points out that some segments are more oriented toward collective goals and challenges, while other segments are more individually oriented. This is in line with the results of the study of $\mathrm{Ng}$ and Burke (2010) who found out that students who are more collective-oriented, tend to be more supportive of sustainable business practices.

\subsection{Discussion}

Sustainability is no longer an optional activity but has become a basic requirement to keep pace with rapid technological development. In academia these efforts include the program itself as well as the staff members (management, administrators, teachers, and researchers), students and workplace (Shafeek, 2020).

In this section, we will discuss the responsibilities of individual participants for the implementation of sustainability in education activities related to it. We will use "Responsibility assignment matrix (RACI MATRIX)" to fulfill this goal (Table 1).

Tab. 1 Responsibility for activities supporting education for sustainability with use RACI Matrix

\begin{tabular}{|l|c|c|c|}
\hline Activities & Management & Teachers/ Researchers & Students \\
\hline Campus green practice & $\mathrm{A}, \mathrm{R}$ & $\mathrm{I}$ & $\mathrm{C}$ \\
\hline University green practice & $\mathrm{A}, \mathrm{R}$ & $\mathrm{I}$ & $\mathrm{C}$ \\
\hline Involvement NGO/ stakeholders & $\mathrm{A}$ & $\mathrm{R}$ & $\mathrm{C}$ \\
\hline Curriculum/ New subject & $\mathrm{A}$ & $\mathrm{R}$ & $\mathrm{C}$ \\
\hline Curriculum / Existing subject & $\mathrm{A}$ & $\mathrm{R}$ & $\mathrm{C}$ \\
\hline Implementation of critical thinking & $\mathrm{A}$ & $\mathrm{R}$ & $\mathrm{C}$ \\
\hline $\begin{array}{l}\text { Implementation of interdisciplinary } \\
\text { approach }\end{array}$ & $\mathrm{A}$ & $\mathrm{R}$ & $\mathrm{C}$ \\
\hline
\end{tabular}




\begin{tabular}{|l|c|c|c|}
\hline Activities & Management & Teachers/ Researchers & Students \\
\hline Implementation theory and practice & $\mathrm{A}$ & $\mathrm{R}$ & $\mathrm{C}$ \\
\hline
\end{tabular}

Source: author's own table

R- responsible (those who do the work to complete the task), A - accountable (final approving authority/ an accountable must approve work that responsible provides), C- consulted (those whose opinions are sought), and I- informed (those who are kept up to date on progress)

The table shows that the greatest responsibility lies with the management and teachers. The role of students is to create pressure to applying concepts of sustainability to the campus and university program. It gives students an impactful way to deeper their commitment to sustainability by using the campus as learning lab for example, to help the waste prevention goals. Implementing items of sustainability on campus can happen quickly but creating a culture of sustainability needs a long time (Shafeek, 2020). There is a shortage of events that promote students to develop sustainable behaviors.

Also, there is a shortage of encouragement from the institution's top management for promotion of social tasks that consider local communities. Cooperation with local NGOs, companies, start-ups or other organizations such as garages, campuses, incubators, funding agencies, coworking spaces, accelerators and innovation centres extend the students' understanding of how each organization contributes to the ecosystem (Chong et.al, 2021).

From previous literature review the most common challenge which faced education sustainability is implementation subjects to university curriculum. Sustainable subjects are discussed only in certain fields in a narrow area. We suggest introducing new subjects into study programs and at the same time/or change existing ones (Table 2).

Tab. 2 Subjects supporting education for sustainability for the program marketing/management.

\begin{tabular}{|l|l|}
\hline \multicolumn{1}{|c|}{ Examples of subjects for marketing/management } \\
\hline \multirow{4}{*}{ New } & Corporate social responsibility \\
\cline { 2 - 3 } & Global citizenship \\
\cline { 2 - 3 } & Circular economy \\
\cline { 2 - 3 } & Sustainable development/ Introduction to sustainability \\
\cline { 2 - 3 } & Driving business towards the sustainable development goals \\
\hline \multirow{5}{*}{ Modified } & Sustainable marketing \\
\cline { 2 - 2 } & Green logistics / Reverse logistics \\
\cline { 2 - 3 } & Socially Responsible Investing \\
\cline { 2 - 2 } & Responsible leadership \\
\cline { 2 - 2 } & Sustainable customer behavior \\
\cline { 2 - 2 } & Sustainability branding \\
\cline { 2 - 2 } & Strategy and sustainability / Green business strategy \\
\cline { 2 - 2 } & Inclusive Leadership: The Power of Workplace Diversity \\
\cline { 2 - 2 } & Cause-related marketing / Social marketing \\
\cline { 2 - 2 } & Sustainability innovation \\
\hline
\end{tabular}




\begin{tabular}{|l|l|}
\hline \multicolumn{2}{|c|}{ Examples of subjects for marketing/management } \\
\hline \multirow{4}{*}{ Supported } & Critical thinking/ Creative thinking \\
\cline { 2 - 2 } & Problem-based learning / Design Thinking \\
\cline { 2 - 2 } & Skills for 21st century \\
\hline
\end{tabular}

Source: author's own table

The main responsibility for changing or committing new subjects lies with the teachers. This requires their constant education in the field of sustainability. We also recommended focusing on skills through active learning courses such as critical thinking, creative thinking, problem solving skills, teamwork. These can be separate, or their principles will be implemented in individual subjects.

Universities across the world are committed to enhancing the role of education for sustainability in the pursuit of sustainable development. There is reason to be confident that the future of education for sustainability will be as rich as its present and past.

\section{CONCLUSION}

The results of this paper are a serious response to the growing need to include sustainability in university curricula: the importance of integrating of transdisciplinary approaches, critical thinking and integration of theory and practice and the importance of knowing about students' values and attitudes needs to be emphasized so that instructors can smartly direct and customize their teaching.

The theoretical contributions are related to introducing the Sterling's three levels of sustainability education and Lambrechts's competences for sustainable development.

Using the "Responsibility assignment matrix (RACI MATRIX)" we describe responsibility for activities supporting education for sustainability. The greatest responsibility lies with the management and teachers to implement subjects supported sustainability to university curriculum. The role of students is to create pressure to applying concepts of sustainability.

Further research could be oriented toward surveys in other higher education institutions, and other study programs, in order to compare different groups of students in different countries. Other recommendations for further research are linking the results of the segmentation studies (Lambrecht) with personal leadership styles, linking the results with specific learning and assessment oriented toward the acquisition of sustainability competences; and linking the results between higher education institutions and efforts to integrate these competences in hiring strategies of companies.

\section{REFERENCES}

Barber, N. (2014). Integrating sustainability into business curricula: university of New Hampshire case study. Int. J. Sustain. High Educ. 15 (4), 473-493 https://doi.org/10.1108/IJSHE-06- 2013-0068.

Bateson, G., (1972). The Logical Categories of Learning and Communication. The University of Chicago Press.

Bask, A. et al., (2020). Business students' value priorities and attitudes towards sustainable development. J. Clean. Prod. 264, 1-9. 
Bilodeau, L. (2014). Advancing campus and community sustainability: strategic alliances in action. Int. J. Sustain. High Educ. 15 (2), 157-168. https://doi.org/10.1108/IJSHE-06-20120051.

Boni, A.,et al., (2019). Educating Engineers for the Public Good Through International Internships: evidence from a Case Study at Universitat Politecnica de Val encia. Sci. Eng. Ethics. 25(6), 1799-1815. https://doi.org/10.1007/s11948-015- 9728-z.

Clark, I.F., \& Zeegers, Y., (2015). Challenging students' perceptions of sustainability using an Earth Systems Science approach. J. Geogr. High Educ. 39 (2), 260-274. https://doi.org/10.1080/03098265.2015.1010142

Cotton, D., \& Alcock, I., (2013). Commitment to environmental sustainability in the UK student population. Stud. High Educ. 38 (10), 1457-1471. https://doi.org/10.1080 /03075079.2011.627423

Dyment, J., \& Hill A. (2015). You mean I have to teach sustainability too? Initial teacher education students' perspectives on the sustainability cross-curriculum priority. Australian Journal of Teacher Education. 40 (3). https://doi.org/10. 14221/ajte.2014v40n3.2.

Ferrer-Balas, D. (2009). Explorations on the University's role in society for sustainable development through a systems transition approach. Case study of the Technical University of $\begin{array}{lllllll}\text { Catalonia (UPC). J. Clean. Prod. } 17 & \text { (12), 1075-1085. }\end{array}$ https://doi.org/10.1016/j.jclepro.2008.11.006.

Filho, L. (2015). Education for sustainable development in higher education: reviewing needs. In: Filho, Leal, Kuznetsova, Brandli (Eds.), Transformative Approaches to Sustainable Development at Universities. Springer International Publishing.

Hesselbarth, C.b (2015). Management education for Fig. 4. Segmentation of business management/marketing students in perspective. W. Lambrechts et al. / Journal of Cleaner Production 202 (2018) 561e570 569 sustainability: deriving learning formats from competence requirements. In: Davim, P.J. (Ed.), Sustainability in Higher Education. Chandos Publishing/ Elsevier Science, Burlington, pp. 21-49.

Hoover, E., Harder, M.K., 2015. What lies beneath the surface? The hidden complexities of organizational change for sustainability in higher education. J. Clean. Prod. 106, 175-188. https://doi.org/10.1016/j.jclepro.2014.01.081

Howlett, C. (2016). Teaching sustainable development in higher education. Int. J. Sustain. High Educ. 173, 305-321. https://doi.org/ 10.1108/IJSHE-07-2014-0102.

Chaplin, G. (2014). Student engagement with sustainability: understanding the value action gap. Int. J. Sustain. High Educ. 15 (4), 404-417. https://doi.org/10.1108/IJSHE-04-2012-0029

Chong, M., Gan, B.K.S., Menkhoff, T. (2021). Enhancing students' global competence through international business study missions. Journal of International Education in Business. 1-21. https://doi.org/ 10.1108/JIEB-06-2020-0054

Klimková, A. (2017). Kompetencie pre udržatel'nost' ako cesta k spravodlivej, starostlivej a udržatel'nej spoločnosti. Edukácia. Vedecko-odborný časopis. 2 (1).

Krizek, K. (2012). Higher education's sustainability imperative: how to practically respond? Int. J. Sustain. High Educ. 13 (1), 19-33. https://doi.org/10.1108/14676371211190281.

Lambrechts, W. et al., (2018). Sustainability segmentation of business students: Toward selfregulated development of critical and interpretational competences in a post-truth era. $\mathrm{J}$. Clean. Prod. 202, 561-570. https://doi.org/10.1016/j.jclepro.2018.07.303 
Leicht, A. (2018). Issues and trends in Education for Sustainable Development. UNESCO Publishing, Paris, France, 276 p. http://unesdoc.unesco.org/images/0026/002614/261445e.pdf

Lozano, R., et al. (2015). A review of commitment and implementation of sustainable development in higher education: results from a worldwide survey. J. Clean. Prod. 108, 1-18. https://doi.org/10.1016/j.jclepro. 2014.09.048.

Moore, J. (2005). Seven recommendations for creating sustainability education at the university level. Int. J. Sustain. High Educ. 6 (4), 326-339. na https://doi.org/10.1108/14676370510623829.

Mulder, K. (2012). How to educate engineers for/in sustainable development. Ten years of discussion, remaining challenges. Int. J. Sustain. High Educ. 13 (3), 211-218. https://doi.org/10.1108/14676371211 242535.

Ng, E.S., Burke, R.J., (2010). Predictor of business students' attitudes toward sustainable business practice. J. Bus. Ethics 95, 603-615. https://doi.org/10.1007/s10551-010-0442-0

Peters, M. (2017). Education in a post-truth world. Educ. Philos. Theor. 49 (6), 563-566. https://doi.org/10.1080/00131857.2016.1264114

Ramos, T.B. (2015). Experiences from the implementation of sustainable development in higher education institutions: environmental Management for Sustainable Universities. J. Clean. Prod. 106, 3-10. https://doi.org/10.1016/ j.jclepro.2015.05.110.

Savelyeva, T., (2012). Escaping the structural trap of sustainability in academia through global learning environments. In: Battels, K.A., Parker, K.A. (Eds.), Teaching Sustainability/teaching Sustainably. Stylus. Sterling, Virginia.

Scott, W., (2002). Education and sustainable development: challenges, responsibilities, and frames of mind. Trumpeter 18 (1). http:// trumpeter.athabascau.ca/index.php/trumpet/article/viewArticle/123/134.

Shafeek, H. (2020). Roadmap for industrial engineering education sustainability. Advances in Science, Technology and Engineering Systems, 5(6), pp. 821-830.

Sterling, S. (2011). Transformative Learning and Sustainability: sketching the conceptual ground. Learn. Teach. High. Educ. 10(5), 17- 33.

https://doi.org/10.3390/su5125347

Sterling, S., (2013). The sustainable university: challenge and response. In: Sterling, S., Maxey, L., Luna, H. (Eds.), The Sustainable University: Progress and Prospects. Routledge, London.

Thomas, I., 2016. Challenges for implementation of education for sustainable development in higher education institutions. In: Barth, M., Michelsen, G., Rieckmann, M., Thomas, I. (Eds.), Routledge Handbook on Higher Education for Sustainable Development. Routledge, London.

Too, L. (2015). Sustainable campus: engaging the community in sustainability. Int. J. Sustain. High Educ. 16 (1), 57-71. https://doi.org/10.1108/ IJSHE-07-2013-0080.

Von Blottnitz, H. (2015). Sustainable development at the core of undergraduate engineering curriculum reform: a new introductory course in chemical engineering. J. Clean. Prod. 106, 300-307. https://doi.org/10.1016/2015.01.063.

UNESCO (2014). Education for Sustainable Development. https://edugog.com/education-forsustainable-development-teacher-guides/

Vladyková, L'. (2015). Úvod do filozofie ekológie. Košice: UPJŠ v Košiciach, Filozofická fakulta, 2015.s. 131. ISBN 978-808152-276-5 
Wals, A.E.J. (2015). Beyond Unreasonable Doubt. Education and Learning for Socio-ecological Sustainability in the Anthropocene. Wageningen, Netherlands: Wageningen University. https://arjenwals.files.wordpress.com/2016/02/8412100972_rvb_inauguratie-wals_ oratieboekje_v02.pdf

Wals, A.E.J. \& Lenglet, F. (2016). Sustainability citizens: Collaborative and disruptive social learning. in Horne, R., Fien, J., Beza B. \& Nelson A. (eds), Sustainability Citizenship in Cities: Theory and Practice. London: Routledge.

Watson, M.K., Lozano, R., Noyes, C. \& Rodgers, M. (2013). Assessing curricula contribution to sustainability more holistically: experiences from the integration of curricula assessment and students' perceptions at the Georgia Institute of Technology. J. Clean. Prod. 61, 106-116. https://doi.org/10.1016/j.jclepro.2013.09.010

Wiek, A. (2014). Integrating problem - and project-based learning into sustainability programs: a case study on the School of Sustainability at Arizona State University. Int. J. Sustain. High Educ. 15 (4), 431-449. https://doi.org/10.1108/IJSHE-02-2013-0013

World Commission on Environment and Development (Wced), 1987. Our Common Future. Oxford University Press, Oxford. World Values Survey (n.d.). http:// www.worldvaluessurvey.org/wvs.jsp.

Zsoka, A. (2013). Greening due to environmental education? Environmental knowledge, attitudes, consumer behaviour and everyday pro-environmental activities of Hungarian high school and university students. J. Clean. Prod. 48, 126-138. https://doi.org/10.1016/j.jclepro.2012.11.030 